This item was submitted to Loughborough's Research Repository by the author.

Items in Figshare are protected by copyright, with all rights reserved, unless otherwise indicated.

\title{
Offending users: designing-in deterrence with mobile telephones
}

PLEASE CITE THE PUBLISHED VERSION

http://dx.doi.org/10.2752/175630611X13046972590888

\section{PUBLISHER}

(C) Berg 2011; Taylor \& Francis (Routledge)

\section{VERSION}

AM (Accepted Manuscript)

\section{PUBLISHER STATEMENT}

This work is made available according to the conditions of the Creative Commons Attribution-NonCommercialNoDerivatives 4.0 International (CC BY-NC-ND 4.0) licence. Full details of this licence are available at: https://creativecommons.org/licenses/by-nc-nd/4.0/

\section{LICENCE}

CC BY-NC-ND 4.0

\section{REPOSITORY RECORD}

McCardle, John, lan J. Storer, George E. Torrens, Shaun Whitehead, Jen Mailley, and Graham Farrell. 2019. "Offending Users: Designing-in Deterrence with Mobile Telephones". figshare.

https://hdl.handle.net/2134/18557. 


\title{
Offending Users
}

\section{Designing in Deterrence with Mobile Telephones}

\author{
John McCardle*, Ian Storer*, George Torrens*, Shaun Whitehead* \\ Jen Mailley**, Graham Farrell** \\ * Department of Design \& Technology, Loughborough University, UK \\ ** Midlands Centre for Criminology and Criminal Justice, Loughborough University, \\ UK
}

\begin{abstract}
This paper describes research relating to the design semantics of desirable products and the crime of theft. The methods employed range from the review of existing designs of mobile phones and associated systems and technologies, the perception of crime from a student designer's viewpoint and, importantly, and the opinions of young offenders about proposed design solutions. We developed conceptual designs in consultation with the Mobile Data Association and these were reviewed by a sample of groups of young offenders and 'non-offender' consumers of similar age, to reflect the different user perspectives. The conclusions reveal differences between offenders and non-offenders in their perceptions of the deterrent effect of different design solutions. It is suggested that the research offers insight into the use of empathic strategies in the design of frequently stolen 'hot products'.
\end{abstract}

\section{Keywords}

social design, design studies, product development, user participation

\section{I ntroduction}

It is well known that mobile data products, particularly mobile phones, have been a key driver of acquisitive crime in recent years. Theft and robbery of mobile phones, for instance, accounts for as much as half of street crime in some areas, and over a quarter of all UK robberies (BBC, 2002; Crimereduction.gov.uk, 2007). Mobile phones and other mobile data products are highly portable by nature, often perceived as valuable and easily disposable, giving them the key characteristics of 'hot products' (Clarke, 1999). In London alone, 10,000 phones are stolen every month and two-thirds of the victims are aged 13-15 (MPS, 2007). The British Crime Survey finds youths are far more likely to be both the victims and offenders in cases of theft and robbery of mobile phones (Harrington \& Mayhew, 2001).

In response, there have been various efforts to tackle mobile phone crime. As well as education campaigns to encourage users to adopt safe practices that reduce the exposure of their phones in public places, there have been design and technological innovations. Phone providers can now block or blacklist stolen phones (Recipero, 2007), removing the financial incentive for some theft and robbery if the handset cannot be used. There have also been studies of mobile phone designs such as those generated under the RSA student design awards. However, there are indicators that the nature of mobile phone and mobile data product crime is adapting to reflect existing crime prevention responses. Increasingly sophisticated and valuable handsets are becoming important independent targets due to the nature of the UK market. It has been suggested that stolen UK mobiles are exported to markets in Africa, Asia and Europe where they continue to work with a new SIM card (BBC, 2003). Whereas UK customers pay little for handsets due to 
incentives to sign-up, they fuel an international market in which they can sell for up to 800 pounds sterling (ibid.).

Approaching crime prevention through product design strategies is an increasing area of interest. Work by Lester (Lester, 2001), has highlighted many of the methods presently used in deterring theft, fraud and other such criminal activities for a broad range of products. However, for electronic goods it further raises issues regarding user acceptance, additional costs, privacy infractions and usability.

The effectiveness of applied crime prevention technology often declines in a relatively short time due to an increase in knowledge of the offenders. This in turn makes such technology obsolete and manufacturers are faced with continually improving older concepts. In light of such adaptations by both manufacturers and offenders, this project sought to make handsets themselves less attractive to thieves. The aim was to assess the likely impact of applying design solutions to mobile telephone handsets that make them less likely to precipitate crime while at the same time retaining the attraction for consumers. The research team involved design and technology experts alongside criminologists, aiming to reflect the different sets of skills required.

The initial stages of the research had two concurrent strands. The first was a review of the relevant crime prevention and criminological literature. The second was a review of existing crime prevention methods and deterrents adopted for a wide range of products. These are described in the next two sections, which are followed by a description of the development of phone design concepts plus preliminary findings from interviews with offenders and phone-user interviews about their perceptions of the deterrent effect of various phone design features.

\section{Preliminary Review of Existing Efforts to Design-Out Phone Theft}

Anti-theft designs relating to mobile phones were reviewed, including the physical and electronic design of handsets. In many instances these included visual deterrents, owner-identification, and handset tracking options. The systems design of phone networks included the blacklisting of stolen phones. A wide range of other design measures included biometric options, and designs that encourage 'safe' phone use and transportation. The research led to a review of policy and procedure relating to phone theft (Mailley et al., 2006a), and a mobile phone theft index which ranked the most stolen makes and models and was inspired by the wellknown car-theft index produced by the Home Office (Mailley et al., 2006b, 2008; Farrell and Mailley, 2007). It also led to a study of the nature and extent of the reprogramming of stolen mobile phones (Kaplankiran et al., 2008) and spin-off work on theft of iPods (Farrell, 2007) and the potential to anticipate crimes relating to the emerging generation of 'smart phones' (Whitehead and Farrell, 2008). Hence the present study is a complementary contribution that examines specific aspects of the research that focused on design and development and assessment of phone design concepts.

The structure of the crime-and-design review reflected the framework developed by the research team for the examination of secure product designs. That framework drew upon earlier work examining the characteristics of stolen products, namely the VIVA (Value, Inertia, Visibility, Accessibility) (Cohen and Felson, 1979), and CRAVED (concealable, removable, available, valuable, enjoyable, disposable) (Clarke, 1999), frameworks. This type of approach has more recently been developed into a crime risk assessment mechanism by Project Marc (Armitage et al, 2006). Each of these studies identified characteristics which can, in some instances, promote the theft of products. 
It is proposed that the characteristics of anti-theft designs should include one or more of a set of characteristics, which surreptitiously form the acronym IN SAFE HANDS: identifiable, neutral, seen, attached, findable, executable, hidden, automatic, necessary, detectable, and secure. The characteristics are detailed in Figure 1. While perhaps 'IN SAFE HANDS' is neither as curt as 'VIVA' nor as catchy as 'CRAVED', the authors considered this to be secondary to that of substance. The set of characteristics might be argued to be a theoretical contribution to the designing-out crime literature. It is intended to promote closer examination of the relationship between design and crime in relation to consumer products in the hope that this may usefully inform design practice.

\begin{tabular}{|c|c|}
\hline I dentifiable & $\begin{array}{l}\text { These are products that are identifiable by their owner. Identification may be, but is not } \\
\text { limited to, visual property marking, such as etching, UV marking or licence plates. }\end{array}$ \\
\hline Neutral & $\begin{array}{l}\text { Anti-theft design features should not adversely affect the user's experience. The feature } \\
\text { should not make a product more difficult to handle or carry, or have other adverse } \\
\text { consequences (for example, RFID can also be intercepted and misused by criminals } \\
\text { seeking to locate valuable products). }\end{array}$ \\
\hline $\begin{array}{l}\text { Seen } \\
\text { (to be } \\
\text { protected) }\end{array}$ & $\begin{array}{l}\text { Being seen to be protected promotes deterrence by increasing the perceived risk. House } \\
\text { and vehicle security are promoted by flashing lights and alarm boxes. }\end{array}$ \\
\hline Attached & $\begin{array}{l}\text { A product which is attached, whether spatially or electronically linked, to its desired } \\
\text { location or owner, will be safer. Computers fixed to room fittings have this characteristic. }\end{array}$ \\
\hline Findable & $\begin{array}{l}\text { If lost or stolen, the product can be tracked and found. Tracker, Lo-Jack, and other car } \\
\text { trackers allow them to be found. A lost or stolen mobile phone might be found by calling } \\
\text { its number. }\end{array}$ \\
\hline Executable & $\begin{array}{l}\text { The product or device can be deactivated or otherwise rendered useless if lost or stolen, } \\
\text { preferably remotely. }\end{array}$ \\
\hline Hidden & $\begin{array}{l}\text { A product which is hidden about the person or otherwise, and not used in an overt } \\
\text { manner. British Crime Survey data suggests } 25 \% \text { of mobile phone thefts involve phones } \\
\text { being used or overtly on display at the time. }\end{array}$ \\
\hline Automatic & $\begin{array}{l}\text { Protection is preferably built-in, the default option, or automated. Credit card PINs are } \\
\text { automated, but mobile phone PIN code locks are rarely used. Lack of automation allows } \\
\text { offenders to take advantage of apathy or ignorance on the part of user-owners. }\end{array}$ \\
\hline Necessary & $\begin{array}{l}\text { It is necessary to be the owner, or to possess information or knowledge held by the owner, } \\
\text { to use a product. This includes mechanical keys, user codes, and biometric information. }\end{array}$ \\
\hline Detectable & $\begin{array}{l}\text { Make it obvious that the product is being stolen or has been stolen. The tamper-proof } \\
\text { design of some product tags clearly reveal when they have been removed to facilitate shop } \\
\text { theft. Exploding ink-dye in money bags means money from bank robberies is easily } \\
\text { detected, to the extent that the cash is effectively worthless. }\end{array}$ \\
\hline Secure & $\begin{array}{l}\text { Product protection should not be easily removable or hackable. The security itself should } \\
\text { be securely designed to pre-empt tactical displacement. }\end{array}$ \\
\hline
\end{tabular}

\section{Figure 1}

Characteristics of secure designs

(Whitehead et al, 2008)

'IN SAFE HANDS' is intended as an adaptable set of characteristics. It is fully expected that the characteristics will be refined to provide better use within specific contexts and flexible enough to encourage designers to consider security in their methodologies. The set of characteristics is presented as a heuristic device to aid designing-out crime from frequently stolen electronic goods (Whitehead et al., 2008). 
The role of product design in crime is now generally recognised (Clarke 1999, 2004; Lester 2001; Gamman and Hughes, 2003; Ekblom, 2005; Clarke and Newman, 2005). To be stolen, a product needs to be both insecure as well as attractive to thieves. In Project Marc for instance (Armitage et al, 2006), sought to quantify the security and vulnerability of electronic products in order to inform crime-proofing efforts. The present study is complementary in its approach. Here, the security and vulnerability of only one type of frequently stolen product is examined by mapping the extent and nature of current anti-theft efforts relating to that product. The aim is to provide a platform for the development of additional efforts to tackle the crime problem.

\section{Design Conceptualisation}

Anti-theft design concepts were developed by involving seventy-two undergraduate students and ten masters-level students of the Design and Technology Department at Loughborough University. They were tasked with producing concepts for more secure mobile phones.

The student's approach to the problem was driven by: the combined findings from the Departments of Design \& technology and Social Science research in this area, the 'IN SAFE HANDS' characteristics and an aesthetic design methodology that guided them in creating product form that expresses specific semantic values, which in this case were derived from theft deterrent principles.

Crime prevention strategies, explained through a series of animal behaviour based analogies, linked to society and product examples, were presented to the students. For example; some butterflies and moths use disguise to alter a predator's perception (Figure 2). The large fake eyes on the wings resemble a much larger animal, which could make a predator pause, thus increasing escape time, or at least deflect them from the real eyes and vulnerable antennae.

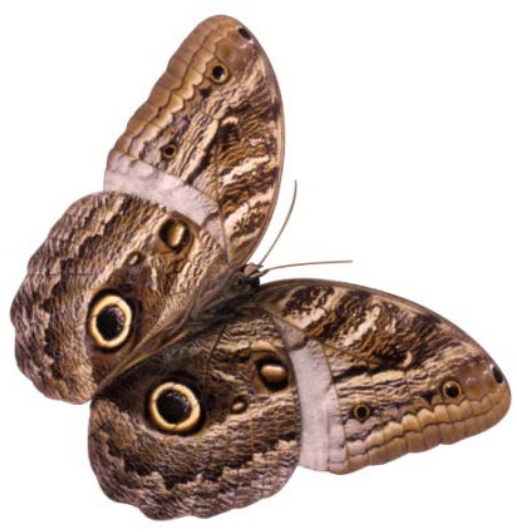

\section{Figure 2}

Butterfly markings mimicking large eyes

As a form of protective bluff

(courtesy of Microsoft Media Elements)

Further examples included: the concept of target removal, such as running away from potential predators, disguise or camouflage as employed by face off car stereos. Common semantic cues, such as warning icons and brightly coloured poisonous insects were presented to further inform the students of the various 
mechanisms by which risks can be reduced (see Cornish and Clarke, 2003 for the set of 25 techniques of situational crime prevention).

The aesthetic design methodology employed, is based on the concept that products possess and project a character that consumers perceive through a filter of their experiences (Lenau \& Boelskifte, 2004) and afford meaning accordingly (Krippendorff, 2006: Krippendorff \& Butter, 1989). For example a product that looks strong is examined to discover exactly what it is about the combination of colour, form and texture that projects the characteristic of strength. Crime deterrent semantic keywords, words that describe the character projected by the product, were derived from a number of areas, notably the research findings, 'IN SAFE HANDS' acronym, brainstorming and animal analogies. Typical examples included, armoured, defensive and secure. Common universal icons and semantics are shown in Figure 3.
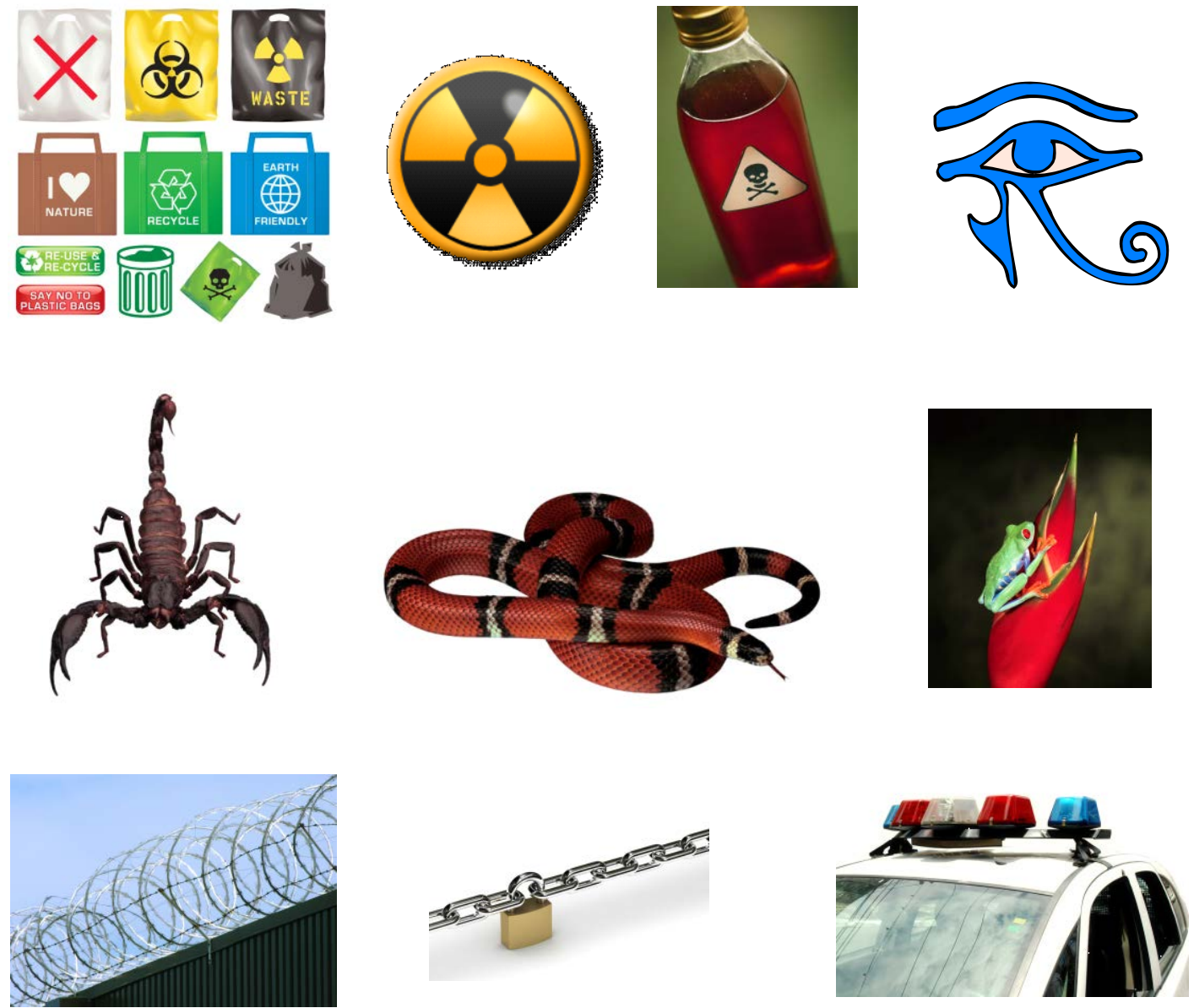

Figure 3

Common semantic cues taken from range of universal icons, defence in nature and product semantics (courtesy of Microsoft Media Elements)

The aesthetic design methodology is described below. 


\section{Step 1: Verbal, semantic briefing}

Semantic ideals, expressed through the form of keywords, that describe the ideal iteration of an imagined final design are chosen. Many words can have similar meanings, so care must be taken to find distinct words that don't overlap significantly.

\section{Step 2: I mage collection}

This stage involves the collection of many images that represent the chosen semantic ideals described by the keywords. This 'divergent' phase of this visual brainstorm encourages wide exploration of imagery without over cautious examination of each image. Contextual, natural, product, automotive, architectural etc images, anything that evokes an appropriate response, are gathered. This step aims to expand the student's scope for inspirational resource. Very natural or abstract imagery can be an useful aid in finding the right mood for the product, however, Storer et al. (2007), considers that undergraduate designers may need more realistic inspiration to aid in the beginnings of form creation. Therefore ten product images that they believe to be in-line with each verbal semantic ideal, e.g. ten secure, ten strong and ten intelligent products are sourced from solely product categories.

\section{Step 3: I mage ranking}

The image collection is filtered against the semantic ideals and the images ranked accordingly. This activity produces a targeted set of appropriate images which when decoded will reveal the aspects of the image that combine to communicate the semantic ideals. The ranking activity refines the collection into a smaller number of images that best articulate the keywords

\section{Step 4: I mage analysis}

The results from the ranking exercise are then analysed using six criteria (illustrated in Figure 4).

Silhouettes: the external elevations of the most appropriate imagery are examined to identifying stance, proportion and direction.

Graphics: The term graphics is used in this instance to describe relationship between the different materials that make up a product. For example a car exterior is broken up by glass, lights, cooling apertures, trim and textured mouldings. Reflections created by sculpted form have similar effects, but for simplicity this is dealt with in the surfacing criteria

Part lines: as with graphics, part lines, the natural openings between panels, mouldings and access points, break the surface area down into subareas and can alter how form is perceived.

Visual weight: How heavy or light a product is perceived to be is often used as an unofficial method to judge quality. The semantic concept of high weight is more commonly used to good effect by manufacturers of high cost goods, such as Rolls Royce cars and Tag Heuer watches. Conversely low weight is desirable in some vehicles, bicycles etc, so the correct visual weight needs to be aligned to the application and keywords. The image collection is thoroughly examined to discover the appropriate visual weight for the keywords. 
Surfacing: The joining relationships between different product surfaces can be manipulated to articulate different semantic messages. Sculpted surfaces can significantly change the perceived product character and be a strong brand identifying characteristic. Automotive designers exploit this aspect of form development to good effect.

Surface Finish: Surface finish is a significant contributor to the perception of the product. Colour, texture, reflective, matt finishes etc or various combinations of can communicate different messages. A reflective surface will be seen very differently to a matt finish. The image search can provide insight into which finishes and combinations are used by products that align with the keywords, and provide a palette of appropriate materials to aid concept design and evaluation.

\section{Synthesis.}

The resultant targeted visual research material is used to drive concept development, and emerging concepts are compared against the findings to ensure that the resultant solutions are appropriate.

\section{Evaluation}

The final designs are presented with the keywords and a collection of the research and analysis data with the aim of providing a convincing story to support the design process.

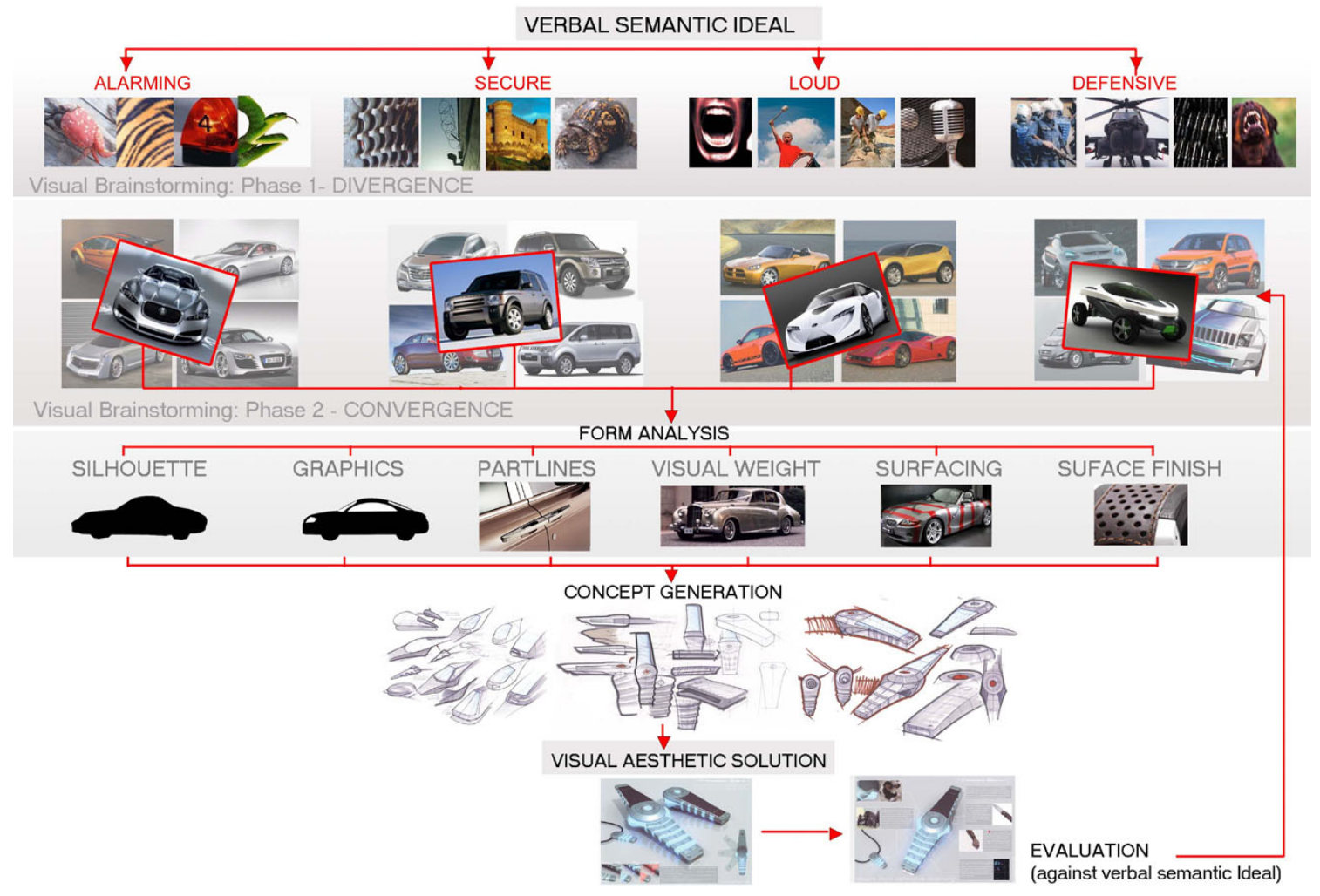

Figure 4

Aesthetic design methodology 


\section{Social context}

The students who were tasked with developing phone designs produced story boards to conceptualise the social context and the type of crime they perceived as being commonplace. Figure 5 illustrates an example of attempted mobile phone theft on a train and the subsequent social shaming of the culprit when a proximity alarm alerts the owner to the theft. It is interesting to note that the storyboard seems to suggest the post-theft humiliation and social conscience are a disincentive in addition to the semantic design of the product as a deterrent. The use of such storyboards was strongly encouraged in this research work as it provided an opportunity to evaluate perceptions of mobile phone crime. For purposes of empathic design methodologies it is interesting to gauge the beliefs, attitudes and ethical stance of students designers who are, by and large, of the same generation as the young offender participants.

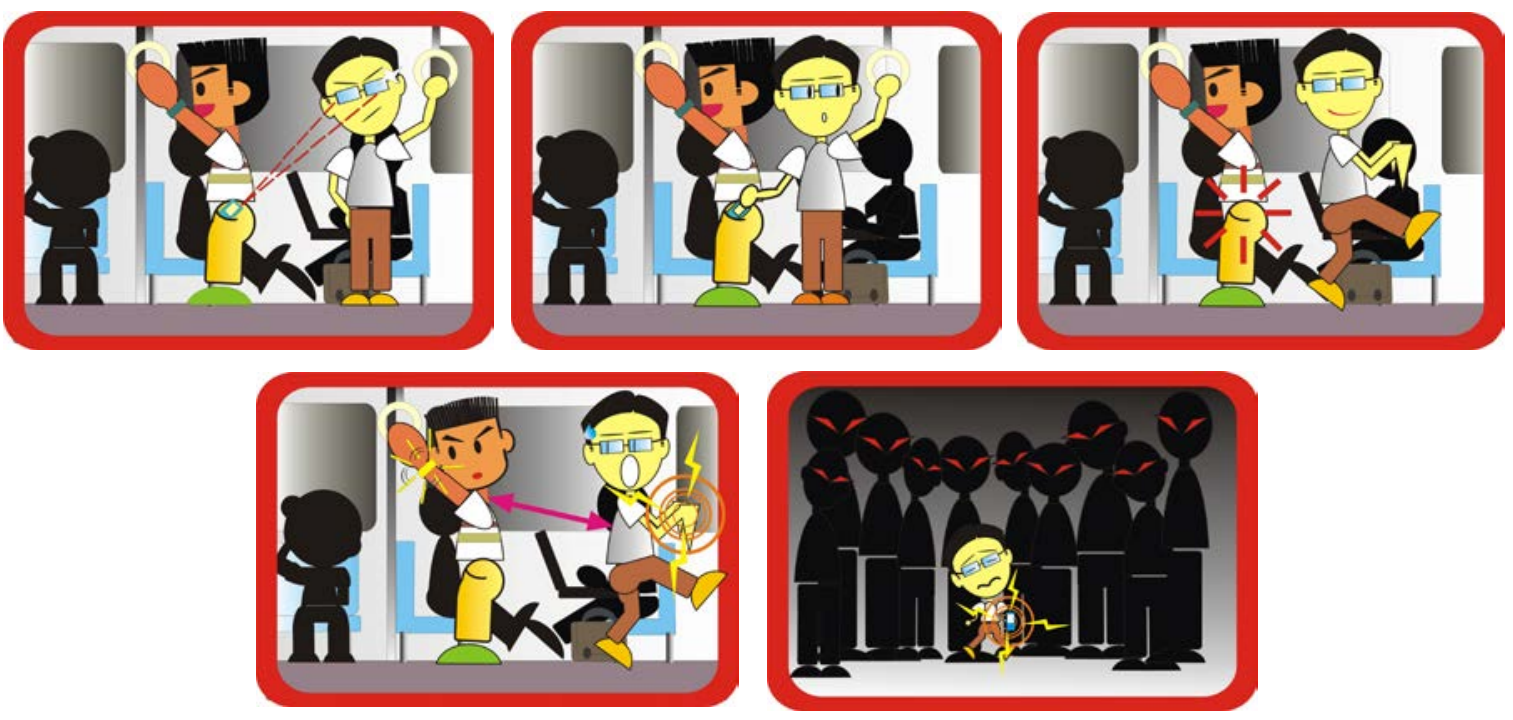

Figure 5

Mobile Phone Crime Storyboard

\section{Designing}

Concept generation driven by crime prevention strategies combined with targeted semantic aesthetic design produced a diverse range of solutions. Two design examples will be presented to illustrate the process.

\section{Design example 1.}

The 'Fortress' phone in Figure 6, is inspired by: bank vaults, pad locks, tank tracks and armadillos, with simple machined surfacing and sharp intersections 

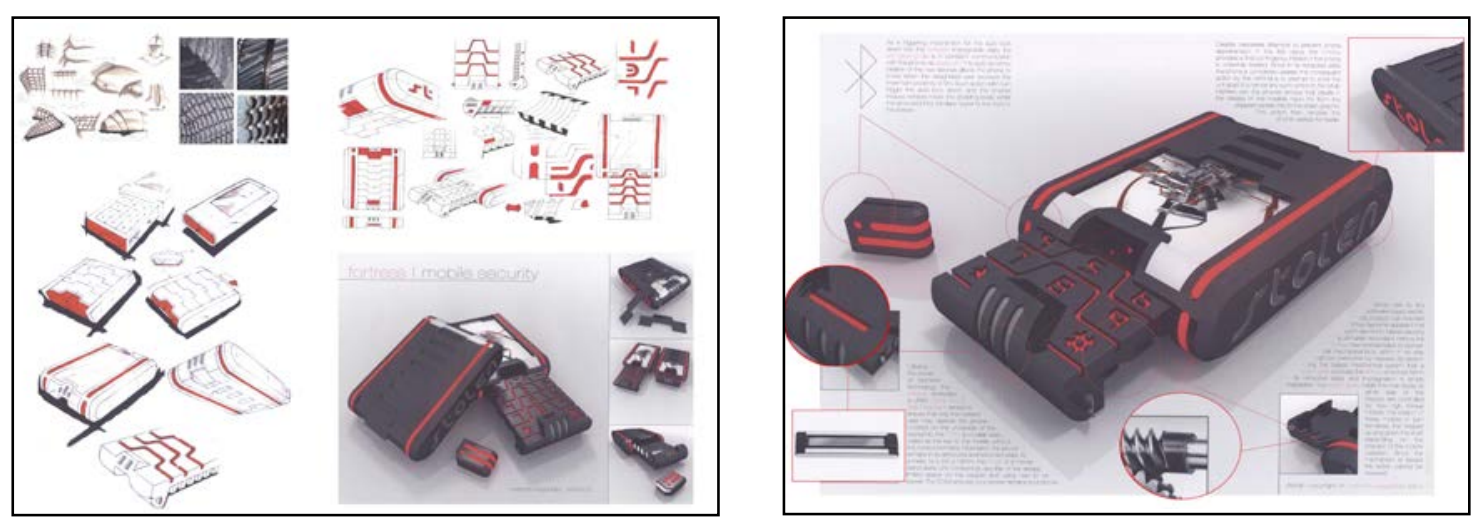

\section{Figure 6}

Mobile phone aesthetic design solution; verbal semantic ideal: armoured, intelligent, mechanised and avert

\section{Design example 2}

The phone in Figure 7, conveys a strong snake-like impression in silhouette, which projects a warning. The knife imagery, generated by the opening mechanism also conveys menace, and the surfacing is largely sharp and 'machined'.
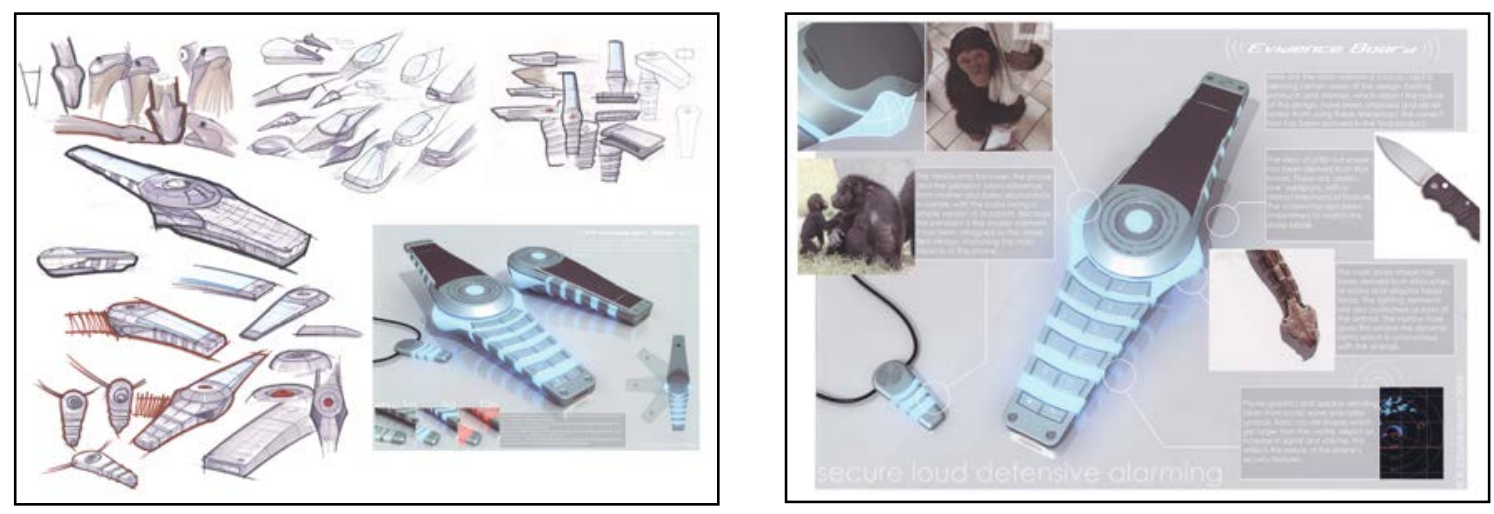

\section{Figure 7}

Mobile phone aesthetic design solution; verbal semantic ideal: secure, loud, defensive and alarming

\section{'User' Review of Design concepts}

The students produced a large spectrum of possible solutions. In depth discussions and design development among the students ensured that a broad range of social criteria could be explored as well as it enabling them to exercise their own personal values, knowledge and aesthetic judgements.

Peer review, and iterative design cycles refined the initial concepts leaving 72 workable solutions. Many concepts shared the same functional deterrent features, utilising one or a number of the 'IN SAFE HANDS' theft deterrent concepts, and many students expressed these concepts through semantic messages communicated through external form. 
The array of individual concept solutions meant that a small subset needed to be identified so they could be presented to offenders and phone-owners as part of a short interviewer. Therefore the concepts were divided into those which were driven by;

1. a common aesthetic/semantic design feature

2. a functional/usability feature

3. a systems adaptation

4. elements of personalisation

5. use of iconography

6. a specific social context.

As examples of these criteria, Figures $8,9,10$ and 11 provide an insight into a common aesthetic design feature such as 'armoured', a functional/usability feature such as 'tethered' and 'wearable' and the application of icons such as the ancient symbol of the protective 'Eye of Horus'. Other concepts such as a ubiquitous phone, a product that is potentially worthless due to its free distribution and cheap manufacture, and existing system de-activation methods were included. Figure 12 provides a tabulated list of the design criteria together with response figures of the participants in the study.

The concepts were then reviewed by the research team and key designs were integrated into the project work alongside those identified elsewhere in the literature review and fieldwork (Whitehead et al, 2008). The review and development of concepts informed the questions that were subsequently asked of offenders and the non-offender comparison group at interview.

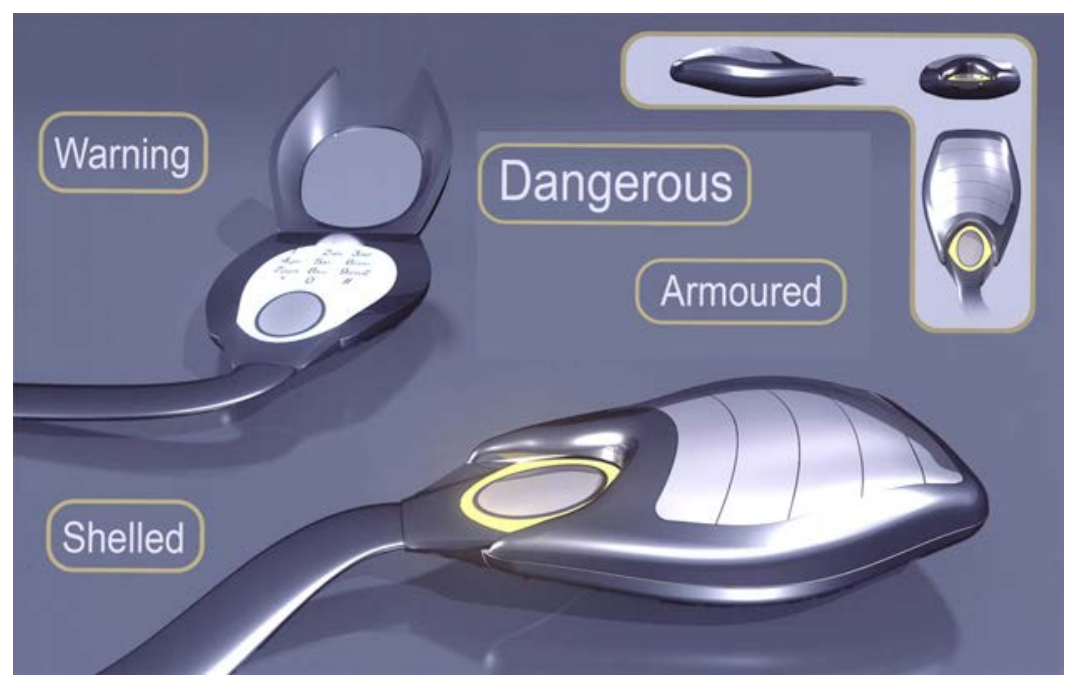

Figure 8

Mobile phone aesthetic design solution:

Armoured, Dangerous and Tethered 


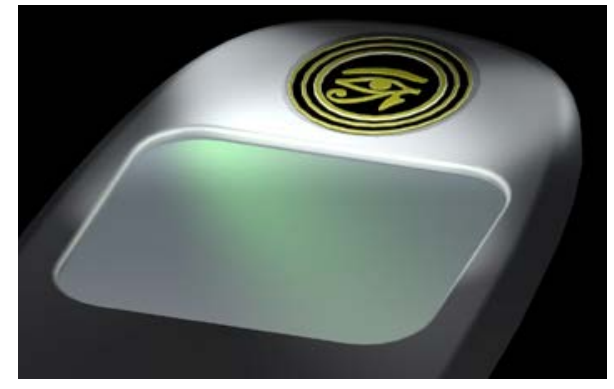

Figure 9

Use of Iconography as a warning symbol

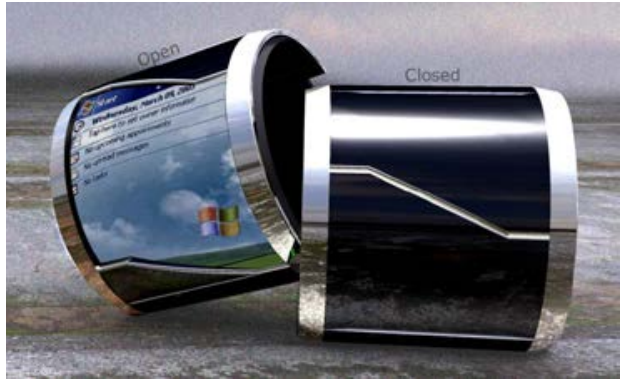

Figure 10

Wrist Wearable Phone

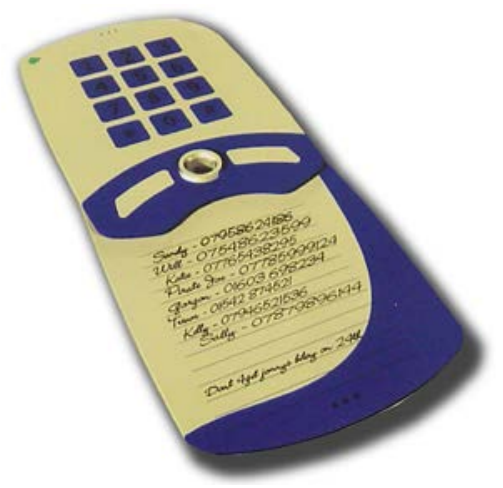

Figure 11

Ubiquitous disposable

Phone

To assess the deterrent effect of different aspects relating to mobile phone design, samples of offenders and non-offenders were then interviewed. A structured questionnaire survey was developed (and piloted) to explore the various design factors. Forty interviews were completed with offenders who were either incarcerated or under probationary supervision. Twenty-eight interviews were conducted at HMP Brinsford Young Offender Institution, 6 at HMP Birmingham, 3 at Staffordshire Intensive Supervisions and Surveillance Programme, and 3 at Leicester City Youth Offending Service. Significant time and research effort went in to gaining access to these institutions. The comparison group of non-offenders was 45 interviews with young people from the student population. The samples were thus roughly matched in terms of age. 


\section{Results}

Figure 12 shows the percentage of participants who claim they would be deterred by a specific design concept.

\begin{tabular}{|c|c|c|c|}
\hline \multirow[b]{2}{*}{ Factor } & \multirow[b]{2}{*}{ Deterrent } & \multicolumn{2}{|c|}{$\%$ Deterred } \\
\hline & & Offenders & $\begin{array}{c}\text { Non- } \\
\text { offenders }\end{array}$ \\
\hline Design & Phone is Biometrically activated & 81.58 & 97.78 \\
\hline Design/System & Tracker fitted in phone & 78.95 & 88.64 \\
\hline Concept/System & Disposable phone & 78.95 & 80.00 \\
\hline Concept/System & Ubiquitous phone - free, everywhere & 62.86 & 79.55 \\
\hline Design & Alarm activated on phone if distant & 57.89 & 44.44 \\
\hline Design/Concept & Phone worn as a Wrist Band & 52.63 & 75.56 \\
\hline Design/System & $\begin{array}{l}\text { Sophisticated reprogramming with changed } \\
\text { chip }\end{array}$ & 47.06 & 70.45 \\
\hline Design/usability & $\begin{array}{l}\text { Have to search person for phone as can only } \\
\text { see their Headset }\end{array}$ & 45.45 & 64.44 \\
\hline Design/l cons & $\begin{array}{l}\text { Eye of Horus symbol warns phone blocked if } \\
\text { stolen (concept) }\end{array}$ & 43.59 & 86.05 \\
\hline System & Phone is blacklisted immediately & 40.54 & 77.78 \\
\hline Concept & Face is Stamped on Phone & 38.46 & 66.67 \\
\hline Design/usability & Phone is worn on a trouser chain & 34.21 & 67.44 \\
\hline Design & $\begin{array}{l}\text { Stolen phone only works as a camera/ MP3 } \\
\text { etc. }\end{array}$ & 29.41 & 62.22 \\
\hline Social Context & Public are watching the theft & 25.00 & 77.78 \\
\hline Design/personalisation & Name is Etched on Phone & 20.51 & 71.11 \\
\hline System & Phone is blocked within 24 hours of theft & 18.42 & 47.73 \\
\hline System & Phone is blocked within 48 hours of theft & 18.42 & 25.00 \\
\hline Design/personalisation & IMEI is Stamped on Phone & 13.16 & 50.00 \\
\hline Design & Alarm activated on owner if phone distant & 13.16 & 31.11 \\
\hline Design/System & Phone blacklisted but is easy to re-programme & 10.53 & 2.33 \\
\hline Design/l cons & $\begin{array}{l}\text { Eye of Horus symbol on phone but no } \\
\text { explanation of it }\end{array}$ & 10.26 & 8.89 \\
\hline Design/personalisation & Owner's name is written on phone & 7.69 & 28.89 \\
\hline Design/Usability & PIN Code needed to unlock phone & 2.70 & 28.89 \\
\hline
\end{tabular}

Figure 12

Comparing offender and non-offender perceived deterrent effects of design factor

\section{Discussion}

Interviews with the non-offender sample suggested that guilt played a role in determining whether or not deterrence was induced. The appeared to be a key distinction between these and the offender interviews. With the personalisation of phones for instance, when asked whether the idea of the stamping the owners face on the phone would put them off, several non-offenders made comments like, 'it Wouldn't be my own' and, 'I would constantly be reminded it was someone else's'. This is in keeping with Cornish and Clarke's (2003) techniques of rule setting as a means of inducing guilt and shame to prevent crime.

Non-offenders seemed relatively unaware of the market for parts. They did not appear to consider the value of the phone beyond its immediate use as a telecommunications device. In comparison, providing an offender was not put off by a tactic such as the blacklisting of a stolen handset (where it is disconnected from 
the network when reported stolen), the reason commonly cited for theft was that offenders believed they could still make some money selling the phone for parts.

Knowledge of the nature of re-programming (changing the identity of a phone by hacking its software) appeared poorer among non-offenders. In addition, most nonoffenders were unaware that they could get a phone unblocked from a keypad lock at market stalls at minimal cost. Although cause and effect could not be identified, it seems reasonable to speculate that the greater knowledge among offenders was the result of involvement in phone theft rather than the cause.

With regards to levels of personalisation, abstract methods such as coded or encrypted symbols and figures illustrated an interesting turn-around. Within a social context non-offenders assumed that the chances of the police stopping them, let alone then checking their phones, were extremely low. Comments by nonoffender interviewees included several such as, 'What are the chances of a random police stop asking to check your phone?'. When asked whether having the IMEI on the outside of the phone was a deterrent to them, offenders didn't make such assumptions as often, perhaps reflecting the different realities and lifestyles of these two groups.

Overall, financial motivations for theft were clearly lacking in the non-offenders responses. Most of their considerations were centred on the implications the design solutions would have on ownership and usability, not resale or parts markets. They were more easily put off by what was perceived as 'effort' and 'hassle', again showing a lack of need for the money from the phones. Nevertheless, it is also noteworthy that the intrinsically 'worthless' ubiquitous phone only presented a deterrent for $\mathbf{2 8 \%}$ of offenders, a lower rate than might have been anticipated as no financial reward could result from the theft.

\section{Conclusions}

It is clear that a range of factors affect a thief's decision to steal mobile phones. However, this research clarified that design has an important role to play in reducing some of the motives behind theft. Design can impact theft by various mechanisms, as evidenced by the differential deterrent effects of the various factors explored in this study. However, among the aspects of design there was little compelling evidence to suggest that specific aspects of semantics and iconography induce significant deterrence when used in isolation and/or without a well publicised meaning. Alternative design features appeared more effective. In particular, biometric activation, tracking and proximity alarms appear likely to generate the most significant deterrent effects. There remains scope for further exploration of several novel design concepts that were identified, particularly the wristband phone, the ubiquitous phone and disposable phone. Since the other key concepts we explored - biometrics, proximity-based alarms, and GPS tracking appear to now be a reality, some more formal evaluation of their preventive mechanisms and effectiveness might be an appropriate next step. Other aspects of mobile phone design and technology, particularly that relating to the IMEI software and a 'number plate' (a visual display of a handset's unique IMEI number on the phone, having a role akin to a car number plate), provide potential avenues for further crime prevention effort and research. The research that complemented that described here, with a focus on designing-out the reprogramming of mobile phones (Kaplankiran et al. 2008), and for stimulating further crime prevention activity by the mobile phone industry (Mailley et al. 2008) present additional crime prevention possibilities. Absent a market incentive, the mobile phone industry appears unlikely to introduce anti-theft designs that incur expense on the part of manufacturers. Market-stimulating tools such as the Mobile Phone Theft Index are required and in 
turn this will provide designers with additional information such as product histories.

Overall, we conclude that the project proved that design has an important role to play in deterring crime. However the aesthetic, and in particular semantic iconography seemed to have little effect in isolation in the present study. The project also identified particular design concepts that may prove fruitful lines of further deterrence research, in particular those concepts whose designers have been mindful of 'IN SAFE HANDS' criteria.

The design methodology employed, which involved design students was, in the view of the research team, a fruitful one. The exercises were well-received and the students engaged in the work with enthusiasm, producing many innovative design concepts. The interviews with young offenders as product 'users' was invaluable in generating market research feedback.

\section{Acknowledgements}

This research was funded by the Engineering and Physical Sciences Research Council under grant EP/C50236X/1. We thank the students of the Design and Technology Department at Loughborough University for their enthusiastic participation in the development of anti-theft phone concepts. In particular we thank the following students for contributing their design work to this research publication; Matt Wagerfield, Adrian Midgley, J oe Wells, Robert Taylor and Cheng Wang. We thank the institutions and facilities that allowed us access to conduct interviews, and all those who took part.

\section{References}

Armitage, R., Clarke, R., Di Nicola, A., Montauti, M., Pease, K., Savona, E. (2006). 'Definition of final crime risk assessment mechanism to measure the risk of theft of electronic products and proof them against theft'. Final Report. University College London: Jill Dando Institute of Crime Science. Accessed J uly 2006 at: http://www.jdi.ucl.ac.uk/downloads/conferences/project_marc/final_report.pdf

BBC, (2002), 'Police target mobile phone thieves', http://news.bbc.co.uk/1/hi/england/1813962.stm, BBC, London, 2002.

BBC, (2003), 'Mobile phone crime blitz launched', http://news.bbc.co.uk/1/hi/uk/3326171.stm, BBC, London, 2003.

Clarke, R. V., (1999), 'Hot Products: understanding, anticipating and reducing demand for stolen goods', Police Research Series Paper 112, Home Office, London, 1999.

Clarke, R. V., (2004), 'Crime proofing of products: The idea and the substance', IEEE Technology and Society Magazine, Fall 2004, 21-27.

Clarke, R. V., and Newman, G., (2005), 'Designing out crime from products and systems', Crime Prevention Studies, Volume 18, Monsey, NY: Criminal Justice Press.

Cohen, L. E. and Felson, M., (1979), 'Social change and crime rate trends: a routine activities approach', American Sociological Review, 44, 588-608. 
Cornish, D.B. and Clarke, R.V., (2003), 'Opportunities, Precipitators and Criminal Decisions: A Reply to Wortley's Critique of Situational Crime Prevention', Crime Prevention Studies, Vol. 16, pp.41-96.

Crimereduction.gov.uk, (2007), 'Street Robbery', http://www.crimereduction.gov.uk/stolengoods2.htm, Home Office, London, 2007.

Crimereduction.gov.uk, (2007), 'Street Robbery', http://www.crimereduction.gov.uk/stolengoods2.htm, Home Office, London, 2007.

Ekblom, P., (2005), 'Designing products against crime', In N. Tilley (Ed.), Handbook of crime prevention and community safety, Willan Publishing, Cullompton, Devon.

Farrell, G., (2007), 'Preventing iPod Theft', Justice of the Peace, 171(11); 191-2.

Farrell, G. and Mailley. J., (2007), 'Phone alert', Police Review, 27 July 2007; 3031.

Gamman, L., \& Hughes, B., (2003), 'Thinking thief: Designing out misuse; abuse and criminal aesthetics', Ingenia J ournal, 35-42, February 2003.

Harrington, V. \& Mayhew, P., (2001), 'Mobile Phone Theft', Home Office Research Study 235, Home Office, London, 2001.

Kaplankiran, T., Mailley, J., Whitehead, S., and Farrell, G., (2008), 'Mobile phone reprogramming: Its extent and prevention', Crime Prevention and Community Safety: An International J ournal, 10(4); 271-279.

Krippendorff, K., (2006), The Semantic Turn, Boca Raton, FL: CRC press. ISBN 0415-32220-0.

Krippendorff, K., and Butter, R., (Eds.) (1989), 'Product Semantics', Design Issues, $5(2)$.

Lenau,T. \& Boelskifte, (2004), 'Communication of Semantic Properties', Working paper, 3rd Nordcode seminar, [PDF] Available:

http://nordcode.tkk.fi/lyngbypapers/nc3_lenau.pdf [accessed on 2007, 3 January]

Lester, A., (2001), 'Crime Reduction Through Product Design', Trends and Issues in Crime and Criminal J ustice, May 2001.

Mailley, J., Whitehead, S., and Farrell, G., (2006a), 'Progress and Prospects in the Prevention of Mobile Phone Theft', Justice of the Peace, 170(22), 404-407. (ISSN 1351-5756).

Mailley, J., Whitehead, S., and Farrell, G., (2006b), 'Bring on the safety razr: the top- 10 stolen mobile phones', J ustice of the Peace, Vol 70, pp. 564-566, $29^{\text {th }}$ July 2006.

Mailley, J., Garcia, R., Whitehead, S., and Farrell, G., (2008), 'Phone theft index' Security J ournal, 21(3), 212-227. 
MPS, (2007), 'Safeguarding your mobile phone', http://www.met. police.uk/crimeprevention/phone.htm, Metropolitan Police, London, 2007.

Recipero, (2007), 'Possession Register', http://www.immobilise.com/home.html, 2007.

Storer, I., Lawson, R., Page, T., (2007), 'Towards a methodology for inspiring and evaluating aesthetic design solutions', Proceedings of the 9th International Conference on Engineering and Product Design Education EPDE07, section: DESIGN MOTIVATION editor: Bohemia E, Hilton K, McMahon C, Clarke A (eds.), pp259-264

Whitehead, S. and Farrell, G., (2008). 'Anticipating mobile phone 'smart wallet' crime: Policing and corporate social responsibility', Policing: A J ournal of Policy and Practice, 2(2); 210-217.

Whitehead, S., Mailley, J., Storer, I., McCardle, J., Torrens, G. \& Farrell, G. (2008), 'IN SAFE HANDS: A Review of Mobile Phone Anti-theft Designs', European Journal on Criminal Policy and Research, 14(1): 39-60. 


\section{Biographies}

Dr J ohn McCardle is a Chartered Engineer \& Senior lecturer in the Department of Design \& Technology, Loughborough University. He is presently Programme Director for the BSc undergraduate degree in Product Design and Technology, which was launched in October 2006. His research interests focus on the cognitive, psychological and physiological effects encountered in the act of designing and the nature, philosophy and culture of design, including design knowledge, design intelligence and design decision making. Within design education the focus is on the knowledge, social acceptance and teaching of technology and the relationship between technology and designing.

Mr I an Storer is a lecturer in the Department of Design and Technology at Loughborough University. He has over ten years experience in the product design industry and has six years experience of teaching Industrial Design at Loughborough University at undergraduate and masters level. He has designed a wide range of transportation, military, consumer and industrial products, both as an independent consultant and as part of design teams. His research has also been funded by the AHRB in the area of product visualisation and task analysis. His research interests include; methods and tools to research, analyse, generate and evaluate aesthetic form; Product semantics and the expression of meaning through aesthetic form; Design visualisation teaching methodologies.

Mr George Torrens is a lecturer in the Department of Design and Technology at Loughborough University. He has undertaken research and design development projects for charitable and commercial organisations, as well as the United Kingdom Government. He currently advises inventors on their designs through the East Midlands Development Agency and The Nottinghamshire Business Venture Trust. His research interests include; Inclusive/Universal Design, The design of Assistive and Rehabilitation Technology (AT/RT) products, Design for Manufacture applied to Small to Medium Enterprises (SMEs) and Human and object interaction.

Mr Shaun Whitehead is a professional engineer and only turned to crime relatively recently. Much of his previous work has been in space engineering. His extensive experience includes working as a senior engineer at Leicester University's Space Research Centre, where he was involved in the JET-X, XMM-EPIC, Beagle 2, XEUS and Swift missions. He has recently worked on designing-out mobile phone theft on an EPSRC-funded project, and from December 2006 will work on an ECfunded project on theft of electronic services.

Ms Jen Mailley completed her MSc in Crime Science at the Jill Dando Institute of Crime Science, University College London in 2005, and holds a BSc in Medical Biochemistry (Genetics). Jen worked for four years as a Forensic Scientist specialising in crimes against the person, before becoming a project manager within the Forensic Intelligence Bureau of the Forensic Science Service. Her research interests include the application of Crime Science to provide practical solution to policing problems; applying Situational Crime Prevention to the area of wildlife and environmental crime, and exploiting the potential of corporate social responsibility as a crime prevention mechanism.

Professor Graham Farrell is Director for the Midlands Centre for Criminology and Criminal J ustice, Loughborough University, UK and conducts research in various areas of crime prevention and criminal justice including in relation to repeat victimisation, policing, cost-benefit analysis and drug policy. 